\title{
Media and expert expectations of long- and short-term effects of the Russian entry to the World Trade Organization on the Russian forest sector
}

\section{Julia Maximova $^{1, *}$, Jouni Pykäläinen² ${ }^{2}$ and Timo Karjalainen ${ }^{3,4}$}

1 Indufor Oy, Töölönkatu 11 A FI-00100 Helsinki Finland; E-Mail: julia.maximova@indufor.fi (M.S.)

2 University of Eastern Finland, Faculty of Science and Forestry, P.O. Box 111 Yliopistokatu 7 , FI-80101 Joensuu Finland; E-Mail: jouni.pykalainen@uef.fi (Prof.Dr.)

3 Natural Resources Institute Finland (Luke), Yliopistokatu 6, P.O. Box 68, FI-80101 Joensuu Finland; E-Mail: timo.j.karjalainen@luke.fi (Res.Prof.Dr.)

4 University of Eastern Finland, Faculty of Science and Forestry, P.O. Box 111 Yliopistokatu 7, FI-80101 Joensuu Finland; E-Mail: timo.karjalainen@uef.fi (Prof.Dr.)

* Author to whom correspondence should be addressed; julia.maximova@indufor.fi (M.S.); Tel.: +358-503-833-732.

Received: 4 October 2015 / Accepted: 25 October 2015 / Published: 25 December 2015

\begin{abstract}
Russian entry to the World Trade Organization in August of 2012 was preceded with a record long history of attempts of joining the Organization and negotiations over terms of accession. However, the accession package was ratified by the Russian State Duma in July of 2012 setting obligations for a number of concessions to the WTO, including significant custom duty reductions for wood products. This has given a handle for a number of speculations and debates whether the membership in the organization regulating the world trade would bring more benefits or drawbacks to the Russian forest industry and trade in wood products.
\end{abstract}

Analyzing diverse opinions of mass media and surveying forest experts has demonstrated that the WTO incorporates a promising long-term potential for boosting the Russian trade in wood products and expanding markets for Russian forest companies. Moreover, the expert community and the media forecast an increased use of forest certification and adjustment of Russian forestry standards to internationally accepted ones. However, both focus groups express concerns over additional competition within the WTO threatening the existence of uncompetitive Russian companies and a raise in prices for domestic timber. All in all, the 
obtained results can support Russian forest authorities in their attempts to neutralize negative short- and long-term impacts of the WTO entry on the Russian forest industry and wood trade, as well as effectively use the possibilities the membership is opening up for the Russian forest sector.

Keywords: World Trade Organization; Russia; export tariffs; wood products; experts and media expectations; WTO membership 


\section{Introduction}

Consultations over Russian accession to the World Trade Organization (WTO) have become a record as the most long-lasting negotiation process in the history of the WTO. It is noteworthy that already in 1944 the USSR took part in Bretton Woods conference, which gave birth to the General Agreement on Tariffs and Trade (predecessor of the WTO), the International Monetary Fund and the World Bank, which formed a framework for international economic cooperation after the Second World War; however since 1946 marked with the beginning of the Cold War, the Soviet Union did not participate in discussions over establishment of the International Trade Organization (ITO) or any of 8 GATT Rounds of Negotiations [1]. The situation for fostering international economic cooperation became even worse in 1951, when the USA refused to grant the Soviet Union an MFN (most-favored-nation) status and increased import duties for goods produced there [1]. However, the USSR did not give up the idea of forming the International Trade Organization and raised this question again in 1954-55, but the idea was once again rejected by the United States [1]. After a long standstill another attempt of the USSR to take part in an open multilaterally regulated trading system took place in 1986, when President Gorbachev asked the GATT for an observer status in the Uruguay Round, as he wanted to end up the economic isolation the USSR was facing during the Cold War [1]. In 1992 after the collapse of the Soviet Union this status was granted and a working group established followed by almost two decades of further negotiations of terms before the final accession in 2012 [1].

Ratification of the accession protocol and Russian final entry to the WTO in August of 2012 has become one of the recent major news events triggering various speculations among economists, politicians, journalists and ordinary people over potential impacts the membership would bring. Undoubtedly one of the main impacts of Russia becoming the 156th member of the WTO has been perceived to be a change in trade tariffs. During the long-lasting period of negotiations Russia has signed 30 bilateral agreements for trade of services and 57 for trade in goods [2]. A decrease in tariffs is sector-specific and an average tariff after the transition period is around $8 \%$ for wood and paper (whereas pre-accession tariff has been 13,4\% on the average) [2]. Export tariffs for sawlogs are now $13 \%$ tariff for spruce and fir logs and $15 \%$ for pine logs (before the accession - $25 \%$ for both but not less than $15 \mathrm{EUR} / \mathrm{m} 3$ ) within a 6,3 and 16 million $\mathrm{m} 3$ quota respectively [3-4]. Logs exported above the quota are a subject to $80 \%$ tariff rate (but not less than $55,2 \mathrm{EUR} / \mathrm{m} 3$ ) [3] making it totally unprofitable both for exporters and importers. The quota is now managed by the Ministry of Industry and Trade of the Russian Federation (Minpromtorg) and another novelty is connected with introduction of one-time wood export license given by the Minpromtorg to forest lessees, who are in good standing with respect to payments of their rent or to businessmen, who have a contract with forest lessees [4].

A document package for obtaining a license for export of wood includes an application, a copy of a foreign trade contract, a document of registration with a tax authority; an evidence of paying a state fee and, if not a forest lessee, a trade contract between a lessee and a buyer of spruce/pine [4]. 
After obtaining a license an exporter also needs to register it with custom authorities [4]. Export tariffs for other sawlogs and wood products have also experienced a considerable tariff reduction. For example, export duty for unprocessed birch logs of any diameter has dropped to $7 \%$ (instead of $15 \%$, but not less than $15 \mathrm{EUR} / \mathrm{m} 3$ before the accession), while almost all other wood products (plywood, particleboard, fibreboard, pulp, paper and paperboard) will be duty free after the end of the transition period and liable to $4 \%$ of custom duty during it.

A hope for more transparent and simplified Russian custom formalities being a WTO member has gradually clashed with the reality - firstly the media has pointed out an increased level of bureaucracy and paperwork for the export of wood products from Russia since the accession. Accession to the WTO has signified a new system of exporting Russian wood - only those companies which have obtained a license from The Ministry of Industry and Trade of the Russian Federation (Minpromtorg of Russia) got a chance to export wood [5]. However, Minpromtorg is distributing these licenses only among the companies which have no debts in paying forest lease (a list of them is provided by the Federal Forest Agency, Rosleshoz) and quite many logging companies, which have been exporting saw logs before, have now been left outside the quota [5]. Paying debts should solve the problem, but the list of indebted lessees is updated only once a year causing logging companies huge financial losses [5]. As the quota has been distributed only among the companies, which have been exporting roundwood during last three years, newly established companies have become not eligible for export within the quota and a more contradictory thing is that some part of export volumes has been assigned to "dead souls" - companies which no longer existed [5]. From another side an import country shall also control the quota by distributing import licenses, like the European Commission to its importers [6]. However, the system is unfamiliar to both sides, what has caused multiple complications like stagnation of export, and it might take some time before it starts to work properly and guarantee a smooth flow of wood through the borders.

Speaking about technological effects and expectations, the forecasted adjustment of Russian technical standards in forestry to international ones has not taken place during the recent time of Russian membership in the WTO. Already in March of 2013 - just half a year after the accession Finland accused Russia of breaking rules of the WTO by impeding the export of softwood logs [7]. Background for these accusations were problems caused by incoherence of softwood logs classifications (EU had 2 classes for softwood logs while Russia - 3) from one side and from another, debts of Russian logging companies due to which they couldn't get export licenses [7]. However, Finland's Minister of European Affairs and Foreign Trade Aleksander Stubb announced that Finland was not going to issue a complaint to the WTO Dispute Settlement Body, but rather try to solve the issue by means of negotiations with the Russian side [8]. The issue gradually vanished, but the first complaint against Russia to the WTO court was still filed in July of the same year by the EU, which questioned Russian "utilization fee" levied from imported cars [9]. On the basis of all this we can note that incoherence of Russian forestry technical standards with those of other member countries of the WTO poses a serious problem affecting its foreign trade and their adjustment should be on the top of the agenda, especially taking into account that distortions for 
trade created by Russia might now have more serious consequences and be complained about in the WTO DSB.

Another short-term effect of new rules of Russian wood trade within the WTO has become a more common conversion of logs into sawnwood of poor quality in order to avoid paying custom duties [10]. The fact that a tariff for processed wood is much lower than for export of logs is encouraging dishonest loggers to play around it and get more income at the expense of worse quality of exported wood and tax payments to the budget [10]. The situation is likely to worsen after the transition period if no legal remedies are introduced in closest future.

One of the recent legal impacts of the WTO on Russian forestry might be also considered an adoption of a list of strategically important goods and resources (in September 2012) - a supplement to the article 226.1 of the Criminal Code of Russian Federation - where wood resources were included into this list and therefore the illegal trade of them has become a criminally punishable act [11]. The maximum punishment for this crime has become a 7-year imprisonment and a substantial monetary penalty [11]. During 2013 the Customs of Siberia have initiated 70 cases in regards to illegal trafficking of wood regulated by the recently modified article 226.1 [12]. Although it can be a disputable fact if the inclusion of wood resources into the supplement has been a result of the WTO accession, some ties of this decision to the membership in the Organization can still be traced, namely in the timing of the law modification and the legal obligation of adjustment of Russian trade legislation to the WTO practices.

Some conclusions can be drawn based on economic, technological and political short-term impacts of the WTO membership discussed above, however the membership in an international organization of such kind has much more far-reaching effect, which cannot be judged about after just few years. Especially in regards to social and ecological effects, which might be visible only in decades, projection of long-term impacts of the WTO membership seems to be much more appropriate and valuable. Thus, the present article aims to shed light on potential opportunities and risks in the Russian forestry within new circumstances of trade in a longer run by analyzing expectations of the two most active groups in the WTO-Russian forestry -debate, namely the mass media and the forest expert community.

\section{Materials and Methods}

The main focus has been placed on longer-term impacts as forests are not natural sources which renew that quickly. Long-term impacts have been presumed to cover the effects which will come out after the so-called "transition period" of Russia within the WTO lasting for up to seven years since the accession and resulting in a gradual decrease of custom tariffs. Another assumption has concerned the nature of sectoral impacts and it has been acknowledged that apart from economic impacts which have received a lot of attention in the WTO-Russian forestry - discussion, political, legal, environmental, social and technological impacts should be also taken into account.

The purpose of the study being understanding and explaining the potential WTO influence on the Russian forest sector has determined the qualitative nature of this paper, therefore qualitative 
research methods have been applied, such as a mass media content analysis and a questionnaire of expert opinion using triangulation and PESTLE tools for the data analysis. The so-called "triangulation approach" has been used in this study in the collection and analysis of the relevant data on potential impacts of the WTO on the Russian forestry. This tool deriving from the navigation and land surveying has been originally applied for identification of a point in space by measuring it from two other points and believed to be highly effective for avoiding biased judgments and other difficulties connected to the use of a single method [13]. The current study has been based on the triangulation of 2 methods of data collection namely media analysis and a questionnaire, what has made it possible to examine expectations regarding the WTO impact on the Russian forest sector from two different angles and get a more representative and accurate picture of potential opportunities and risks associated with it.

For the identification of attitudes of the forestry-related media in regards to the potential influence of the WTO on the Russian forest sector 10 analytical articles have been chosen giving light to this issue. For 3 of them forestry was the main focus - Ukrainski lisovod [14], Lesnaya industriya [15] and Rossiyskiye lesnye vesti [16], 2 articles were representing regional media Krasnyi sever [17] and Expert Severo-Zapad [18], 3 were published by the major news agencies in Russia - Ria Novosti [19], [20] and Rbk Daily [21], one - by the business-oriented radio portal Business FM [22] and the last one was a short TV talk-show, Rbk video [23]. This specific media was chosen due to its high relevance for the purpose of this study, diversified opinions and credibility and was subjected to a thematic analysis. All revealed attitudes were examined according to the frequency of their mentioning in selected articles, which allowed foreseeing certain trends in media coverage of the Russian accession to the WTO and its influence on the forest sector.

Next step has been the determination of the Russian forest expert community's opinions in regards to the WTO impact and this has been done by the means of conducting a questionnaire. The questionnaire form was designed in Google Drive - a free web-based platform for creation of various documents due to the simplicity of its use and sharing and a link to the questionnaire was sent to respondents by email in an accompanying cover letter explaining the aim and scope of the study, ensuring confidentiality and stating the timeframe (answers were being gathered during two weeks - from March, 3 to March, 17 2014).

Qualitative nature of the current study predetermined the choice in favor of open-ended questions, where respondents were asked to list expected positive and negative changes in the forest sector due to the Russian membership in the WTO. In addition to that, other valuable unstructured data was gathered by asking experts if the Russian accession to the WTO had anyhow affected their company/institution. Nevertheless, two closed-ended questions were also included into the questionnaire in order to identify a type of the company (forest research institute, wood processing company, logging enterprise, governmental authority, custom authority, NGO/environmental protection, forest certification or any other) and its size (small - less than 50 employees, medium 50-250 employees or large - more than 250; according to the definition given by the European Commission). Industrial companies were also asked to give approximate numbers of their annual 
turnover (in RUB or EUR) and the share of export from the total production (in \%), what could have been useful for determining their scale of production and position in export of wood products. As all participants were promised confidentiality in relation to their names and companies, they were only asked to state a position in an institution or a company they represented.

Likewise in the majority of qualitative research studies a non-probability sampling was used for conducting the questionnaire, leaving a researcher a right to chose participants according to his own judgment in regards to their relevance to the study [24]. The non-probability sampling technique applied in the present questionnaire was a synthesis of purposive and convenience sampling [24], as targeted experts were believed to have most competence in addressing questions of the RussiaWTO-forestry dimension and their contact details were easy enough to find. A total of 38 experts were selected for participation in the questionnaire representing 10 biggest Russian forest companies and 6 foreign ones having production facilities in Russia, 5 institutions specializing in forest-related research, 6 Russian governmental bodies, 4 environmental NGOs, 2 companies dealing with forest certification and 5 other. The bias in the selection of participants, which nonprobability sampling is often blamed for [24], was tried to be reduced by the triangulation of data collected from the questionnaire with the one collected from the mass media.

The process of analyzing collected material started with extracting relevant forest sector-related expectations associated with the Russian accession to the WTO and determining the frequency of their mentioning throughout media articles and responses of experts. Depending on the positive or negative character of these expectations they were further subdivided into opportunities and risks in order to be able to make a relative judgment about the general attitude of forest experts and journalists towards new frames in which the Russian forest industry and wood trade occur. However, determining the character of expressed attitudes would seem incomplete only by splitting them into opportunities and risks, therefore they were also subjected to the so-called PESTLE analysis (also known as PESTEL, STEEP or PEST analysis). As a qualitative research tool PESTLE stands for a synthesis of political, economic, social, technological, legal and environmental analysis of the outcomes of a specific driver on a macro-environment of a corporation or industry [25]. This tool is rather wide-spread for the identification of external risks and opportunities in the business environmental analysis and determination of a company/industry strategy [25]. In the present study PESTLE has served as a general frame of reference for the revealed media and expert attitudes allowing determining where the main focus of both stakeholder groups is shifted to - politics, economics, social sphere, technology, legislation or ecology.

The triangulation approach chosen for the application in the current study in regards to the data analysis required cross-verification of identified opportunities and risks. This has been done by comparing them among each other and revealing those opinions of journalists and experts which are identical or contain a similar message. Such cross-validation has made it possible to form a final judgment in regards to most probable opportunities and risks for the Russian forest sector within the WTO and, from another side, eliminated potential bias in the course of data collection and analysis, as well as contributed to achievement of more reliable results of the study. 


\section{Results}

\section{Media expectations towards the effect of the WTO on the Russian forest sector}

Russian media has been active in the debate over the accession to the WTO and forestry-related media has not been an exception either. Generally speaking the media coverage is far from having a common consent over the effects the WTO can bring to the forest sector and points out various opportunities and risks linked to this far-reaching decision. Let us have a closer look at WTOrelated expectations of authors of the selected articles (Table 1).

The Ukrainski lisovod [14] together with the Expert Severo-Zapad [18] have offered the most comprehensive and balanced combination of possible positive and negative effects of the WTO on the Russian forestry. The most optimistic attitude has been expressed by Rossiyskiye lesnye vesti [16], while the most pessimistic - by Krasnyi sever [17], Rbk Daily [21], Business FM [22], Ria Novosti (2) [19] and Rbk video [23] offering just one positive outcome in the raw of multiple negative. In Lesnaya industriya (Lesnaya industriya 2012) possible risks of the accession into the WTO also prevail. Finally, Ria Novosti (1) [20] is the only article which has been dealing with the environmental aspect of the topic rather than economical (Table 1).

According to the frequency of mentioning we can note that the most popular positive effects of the WTO the media tends to forecast are an increased flow of investments into the Russian forest sector, as well as more available forest machinery, materials and chemicals, what can contribute to modernization of the Russian forest industry and an improved quality of Russian forest products. These two trends are mentioned by half of the media or mentioned in 5 articles out of 10 under examination. Another popular opinion among media experts is that the WTO will improve the access of Russian companies and forest products to international markets and will trigger the process of adjustment of Russian technical standards in forestry to international ones along with more wide-spread use of forest certification. These attitudes are supported by third of the authors ( 3 articles from 10). Less popular outcomes of accession tend to be in the development of more transparent and simplified custom formalities, more competitive prices for wood products and more intensive logging expressed by 2 articles respectively. The least supported attitudes include adopting environmental laws brought in line with international ones, harmonizing Russian woodtrade related legislation with other members of the WTO, an increased trade in round wood and establishment of foreign companies in Russia (1 out of 10).

Other single opinions point out a possible introduction of clear and transparent mechanisms of control over the implementation of forest protection legislation, development of ecologicallyfriendly industries, abandonment of Russian ecological protectionism, intensified use of wood pellets due to higher prices of natural gas and a bigger profit for SME due to cheaper raw materials. 
Table 1 Anticipated changes in the Russian forest sector due to the WTO membership and frequency of their mentioning (according to the mass media)

\begin{tabular}{|c|c|c|c|c|c|c|c|c|c|c|}
\hline & $\begin{array}{l}\text { Ukrain } \\
\text { ski } \\
\text { lisovod }\end{array}$ & $\begin{array}{l}\text { Krasnyi } \\
\text { sever }\end{array}$ & $\begin{array}{l}\text { Lesnaya } \\
\text { industriya }\end{array}$ & $\begin{array}{l}\text { Rossiyskiye } \\
\text { lesnye vesti }\end{array}$ & $\begin{array}{l}\text { Rbc } \\
\text { daily }\end{array}$ & $\begin{array}{l}\text { Expert } \\
\text { Severo } \\
\text {-Zapad }\end{array}$ & $\begin{array}{l}\text { Ria } \\
\text { Novosti } \\
\text { (1) }\end{array}$ & $\begin{array}{l}\text { Business } \\
\text { FM }\end{array}$ & $\begin{array}{l}\text { Ria } \\
\text { Novosti } \\
\text { (2) }\end{array}$ & $\begin{array}{c}\text { Rbc } \\
\text { video }\end{array}$ \\
\hline $\begin{array}{l}\text { Better availability of foreign forest machinery, } \\
\text { materials, chemicals and spare parts; more } \\
\text { intensive modernization and better quality of } \\
\text { Russian forest products }\end{array}$ & $\bullet$ & & $\bullet$ & $\bullet$ & & $\bullet$ & $\bullet$ & & & \\
\hline $\begin{array}{l}\text { Easier access of Russian wood products to foreign } \\
\text { markets }\end{array}$ & $\bullet$ & & & & & $\bullet$ & • & & & \\
\hline More transparent and easier custom formalities & $\bullet$ & & & $\bullet$ & & & & & & \\
\hline $\begin{array}{l}\text { Adjustment of Russian technical standards in } \\
\text { forestry to international ones; increased use of } \\
\text { forest certification }\end{array}$ & • & & • & & & & $\bullet$ & & & \\
\hline $\begin{array}{l}\text { Adoption of environmental laws sound with } \\
\text { international }\end{array}$ & & & & & & & $\bullet$ & & & \\
\hline $\begin{array}{l}\text { Harmonization of Russian wood-trade related } \\
\text { legislation with other members of the WTO }\end{array}$ & $\bullet$ & & & & & & & & & \\
\hline More competitive prices for forest products & & $\bullet$ & & $\bullet$ & & & & & & \\
\hline Increased amount of logging & & & & $\bullet$ & & $\bullet$ & & & & \\
\hline Increased trade in round wood & & & & $\bullet$ & & & & & & \\
\hline Increased amount of foreign companies in Russia & & & & • & & & & & & \\
\hline $\begin{array}{l}\text { Clear and transparent mechanisms of control over } \\
\text { the implementation of forest protection legislation }\end{array}$ & & & & $\bullet$ & & & & & & \\
\hline $\begin{array}{l}\text { More investments into wood processing industry, } \\
\text { logging and ecologically-friendly manufacturing } \\
\text { (incl. foreign investments); more transparent and } \\
\text { attractive investment climate }\end{array}$ & & & & $\bullet$ & $\bullet$ & $\bullet$ & $\bullet$ & $\bullet$ & & \\
\hline Development of ecologically-friendly industries & & & & & & & $\bullet$ & & & \\
\hline Less ecological protectionism & & & & & & & $\bullet$ & & & \\
\hline $\begin{array}{l}\text { Intensified use of wood pellets due to increased } \\
\text { prices of natural gas }\end{array}$ & & & & & & & & & $\bullet$ & \\
\hline $\begin{array}{l}\text { Increased profit for SME due to cheaper raw } \\
\text { materials }\end{array}$ & & & & & & & & & & $\bullet$ \\
\hline $\begin{array}{l}\text { Increased competition of foreign companies; } \\
\text { disappearance of uncompetitive russian } \\
\text { companies, increase of unemployment, decrease }\end{array}$ & $\bullet$ & $\bullet$ & $\bullet$ & $\bullet$ & $\bullet$ & $\bullet$ & & & $\bullet$ & $\bullet$ \\
\hline
\end{tabular}




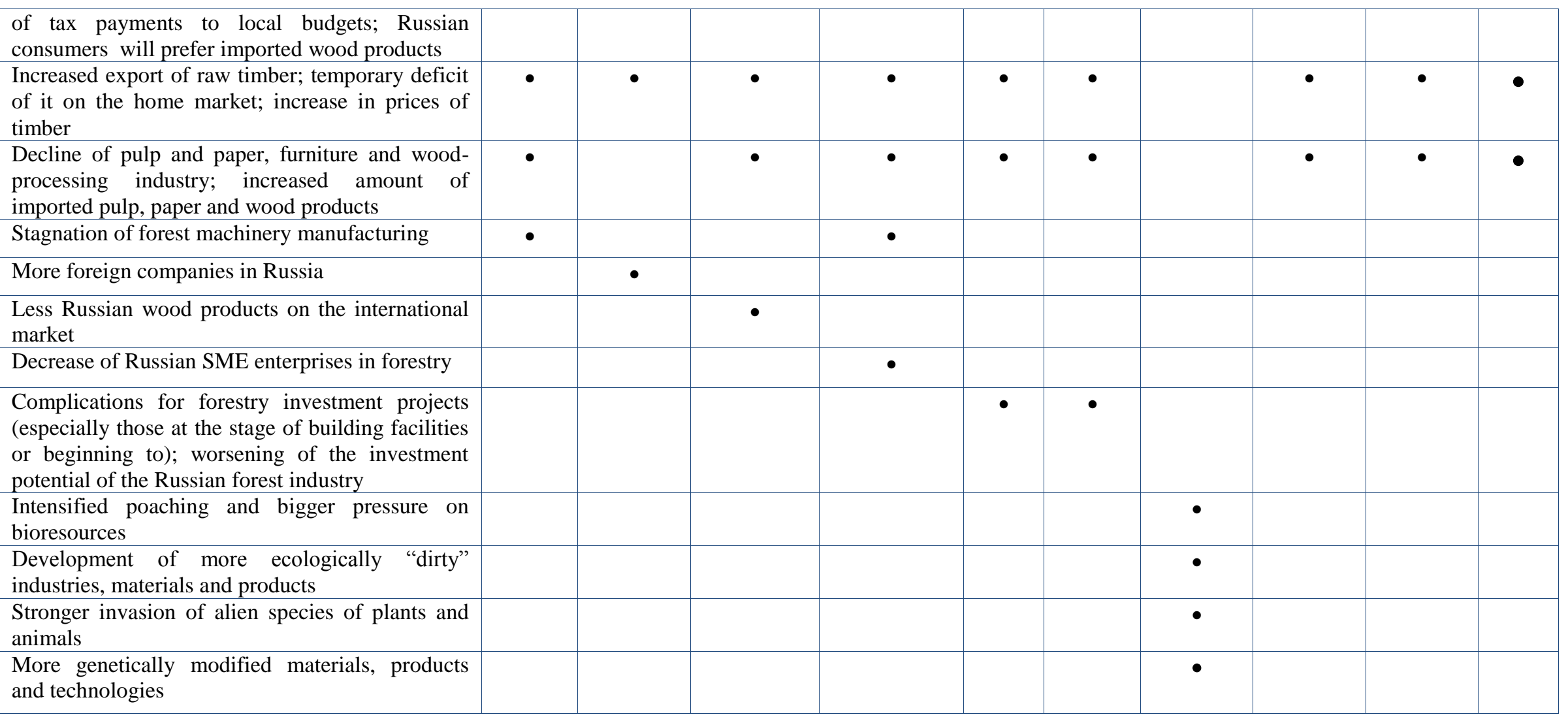


Turning to negative attitudes of the media coverage, it is hard to object that the selected media tends to foresee also various pessimistic outcomes of the WTO on the Russian forest sector. The majority of experts (9 out of 10) expect more export of raw timber from Russia leading to a temporary deficit of it and a rise of prices of timber on the domestic market. Another highlyexpected outcome of the WTO is a bigger competition of foreign companies resulting in a collapse of uncompetitive Russian companies together with increased unemployment, less tax payments to local budgets and Russian consumers' switch to imported wood products - all expressed in opinions of 8 our of 10 analytical reports. Other expected risks of the WTO accession were less unanimous (2 articles) stating a possibility of stagnating forest machinery manufacturing and emerging complications for forestry investment projects. Only one article was mainly concerned with environmental risks of the membership, which might provoke intensified poaching and higher degree of pressure on bioresources, creation of more ecologically "dirty" industries, materials and products, as well as an invasion of alien plant and animal species together with spreading of genetically modified materials, products and technologies. While an increased amount of foreign companies in Russia has been mentioned in the list of opportunities, one author tends to believe that it can pose a risk for the Russian forest industry. The same situation is with SME enterprises, where one article has included an increased profit for forest small and medium-sized enterprises into a positive effect, but another considers that the WTO might contribute to their disappearance. Another single opinion states that there can be a risk of emerging difficulties for Russian wood products to enter the international market.

Previously discussed attitudes have been further subdivided into opportunities and threats depending whether they are believed to bring benefits or risks to the Russian forest sector (Table 2). This table demonstrates that despite the amount and the variety of potential negative outcomes of the WTO for the Russian forestry, positive attitudes still prevail and the accession is associated with more opportunities rather than threats it might bring.

Table 2 Potential opportunities and threats for the Russian forest sector within the WTO (according to the mass media)

\begin{tabular}{|l|}
\hline $\begin{array}{l}\text { Better availability of foreign forest machinery, materials, chemicals and spare parts; more intensive modernization } \\
\text { and better quality of Russian forest products }\end{array}$ \\
\hline Easier access of Russian wood products to foreign markets \\
\hline More transparent and easier custom formalities \\
\hline Adjustment of Russian technical standards in forestry to international ones; increased use of forest certification \\
\hline Adoption of environmental laws sound with international \\
\hline Harmonization of Russian wood-trade related legislation with other members of the WTO \\
\hline More competitive prices for forest products \\
\hline Increased amount of logging \\
\hline Increased trade in round wood \\
\hline Increased amount of foreign companies in Russia \\
\hline
\end{tabular}




\begin{tabular}{l} 
Clear and transparent mechanisms of control over the implementation of forest protection legislation \\
\hline $\begin{array}{l}\text { More investments into wood processing industry, logging and ecologically-friendly manufacturing (incl. foreign } \\
\text { investments); more transparent and attractive investment climate }\end{array}$ \\
\hline Development of ecologically-friendly industries \\
\hline Less ecological protectionism \\
\hline More intensive use of wood pellets due to increased prices of natural gas \\
\hline Increased profit for SME due to cheaper raw materials \\
\hline $\begin{array}{l}\text { Increased competition of foreign companies; disappearance of uncompetitive Russian companies, increase of } \\
\text { unemployment, decrease of tax payments to local budgets; Russian consumers will prefer imported wood products }\end{array}$ \\
\hline Increased export of raw timber; temporary deficit of it on the home market; increase in prices of timber \\
\hline Decline of pulp and paper, furniture and wood-processing industry; increased amount of imported pulp, paper and \\
wood products \\
\hline Stagnation of forest machinery manufacturing \\
\hline More foreign companies in Russia \\
\hline Less Russian wood products on the international market \\
\hline Decrease of Russian SME enterprises in forestry \\
\hline Complications for forestry investment projects (especially those at the stage of building facilities or beginning to); \\
worsening of the investment potential of the Russian forest industry \\
\hline Intensified poaching and bigger pressure on bioresources \\
\hline Development of more ecologically "dirty" industries, materials and products \\
\hline Stronger invasion of alien species of plants and animals \\
\hline \hline More genetically modified materials, products and technologies \\
\hline
\end{tabular}

Having identified all the opportunities and risks the media expresses in regards to Russian forestry within the frames of the WTO has also made it possible to examine their nature and the most logical way to do that seemed to be the so-called PESTLE analysis. The majority of expected effects are of an economic nature (14 factors), what seems to be reasonable as the Organization is mostly dealing with trade issues. A considerable impact is forecasted to be on the environment as well (6 factors), what can be explained by the fact that natural resources are at the scope of the debate. 3 factors are of a legal nature, as membership in the WTO generally requires a wide adjustment of national legislation. Technological and political effects seem to be less assumed by the media, however their importance can not be denied. The least impact the WTO is expected to have on a social sector if judged according to the attitudes of the Russian media (Table 3). 
Table 2 PESTLE analysis of anticipated changes in the Russian forest sector due to the WTO membership (according to the mass media)

\section{POLITICAL}

- Less ecological protectionism - More transparent and easier custom formalities
- More competitive prices for forest products

- Increased trade in round wood

- Increased profit for SME due to cheaper raw materials

- Easier access of Russian wood products to foreign markets

- Increased amount of foreign companies in Russia

- More investments into wood processing industry, logging and ecologically-friendly manufacturing (incl. foreign investments); more transparent and attractive investment climate

- More intensive use of wood pellets due to increased prices of natural gas

- Complications for forestry investment projects (especially those at the stage of building

facilities or beginning to); worsening of the investment potential of the Russian forest industry

- Decrease of Russian SME enterprises in forestry

- More foreign companies in Russia

- Less Russian wood products on the international market

- Stagnation of forest machinery manufacturing

- Decline of pulp and paper, furniture and wood-processing industry; increased amount of imported pulp, paper and wood products

ncreased export of raw timber; temporary deficit of it on the home market; increase in prices of timber

- Increased competition of foreign companies; disappearance of uncompetitive Russian companies, decrease of tax payments to local budgets; Russian consumers will prefer imported wood products

\section{TECHNOLOGICAL}

\section{LEGAL}

- Adoption of environmental laws sound with international

- Harmonization of Russian wood-trade related legislation with other members of the WTO

technical standards in forestry to international ones; increased use of forest certification

- Better availability of foreign forest machinery, materials, chemicals and spare parts; more intensive modernization and better quality of Russian forest products
SOCIAL

- Increase of unemployment

ENVIRONMENTAL

- Increased amount of logging

- Development of ecologically-friendly industries

- Intensified poaching and bigger pressure on bioresources

- Development of more ecologically "dirty" industries, materials and products

- Stronger invasion of alien species of plants and animals

- More genetically modified materials, products and technologies 


\section{Expert expectations towards the effect of the WTO on the Russian forest sector}

Determining potential changes in the Russian forestry due to new rules of play set by the membership in the WTO would not be complete without turning to an expert community asking for their opinion on the matter. Therefore, an online questionnaire has been designed and sent to 38 preselected experts asking them to list their expectations in regards to changes in Russian forestry within the WTO. During two-week response time (March, 3 - March, 17) the questionnaire was filled in by 5 participants including 3 CEOs, 1 manager and 1 expert, resulting in a $13 \%$ response rate. All of the participants represented either an NGO (3) or a forest research organization (2), thus neither governmental officials nor forest industry stakeholders have demonstrated an interest for participation. Concerning a size of the respondents' companies, 2 of them were large companies employing more than 250 people and 3 small-sized with less than 50 employees. The questions regarding an annual turnover and an approximate share of the export from total production have not turned out to be relevant, as it has been previously mentioned that there has not been any response from the forest industry.

Turning to focal questions of the questionnaire regarding the potential influence of the WTO on the Russian forest industry and trade, 3 out of 5 experts stated that they had not experienced any or any considerable changes connected to the membership in the WTO so far. Nevertheless, one of them points out a positive change - an increased interest towards Russia (partly caused by the accession to the WTO) has triggered additional interest to the Russian research conducted by this forest research institution. The last respondent - though not explicitly referring to how this matter has affected his company - expresses a concern over recent Russian violation of the WTO rules in the form of an increase in import tariffs for paper and paperboard products, as well as hindering export of roundwood. Though according to responses experts have not been much concerned about short-term effects of membership, they have tended to forecast a wide range of positive and negative trends in the Russian forestry under the WTO in a longer term. A list of them has been compiled in the following table:

It demonstrates that experts are mostly concerned about a possibility of an increased competition in the Russian forest sector, what has been stated by 3 out of 5 experts. 2 out of 5 experts anticipate negative outcomes of revealed non-competitiveness of Russian companies in production of deeplyprocessed wood products of high quality, as well as high risks and inequality in wood market competition due to introduction of export quotas. Additional problems in the Russian forest sector (a single opinion) might be caused by a rise in prices of timber due to higher amount of spendings on forest certification. From another side, experts forecast several positive outcomes as the result of the WTO membership, namely a higher popularity of wood products coming from certified sources, better access of Russian companies into international markets and intensified wood trade ( 2 out of 5 experts respectively). Other single expectations included a facilitated process of legalization of tree logging in Russia, non-discrimination and transparency in Russian wood trade due to obligations as the WTO member, as well as the control over wood products. 
Table 4 Anticipated changes in the Russian forest sector due to the WTO membership and frequency of their mentioning (according to forest experts).

\begin{tabular}{|c|c|c|c|c|c|}
\hline & Expert 1 & Expert 2 & Expert 3 & Expert 4 & Expert 5 \\
\hline $\begin{array}{l}\text { Easier access of Russian forest companies to } \\
\text { foreign markets }\end{array}$ & & $\bullet$ & $\bullet$ & & \\
\hline $\begin{array}{l}\text { Russia will have to follow the WTO rules; a lower } \\
\text { possibility for discrimination of foreign forest } \\
\text { companies; more transparency in wood trade }\end{array}$ & & & & & $\bullet$ \\
\hline $\begin{array}{l}\text { The priority in trade will be given to wood } \\
\text { products coming from certified sources }\end{array}$ & $\bullet$ & $\bullet$ & & & \\
\hline Increased control for wood products & & $\bullet$ & & & \\
\hline $\begin{array}{l}\text { Increased competition in the forest sector (also } \\
\text { from abroad) }\end{array}$ & & & $\bullet$ & $\bullet$ & $\bullet$ \\
\hline Legalization of tree logging & & $\bullet$ & & & \\
\hline Increased trade in wood & & & & $\bullet$ & $\bullet$ \\
\hline $\begin{array}{l}\text { Non-competitiveness of Russian companies in } \\
\text { producing wood products of high quality and deep } \\
\text { processing }\end{array}$ & $\bullet$ & $\bullet$ & & & \\
\hline $\begin{array}{l}\text { More expensive timber due to increased spendings } \\
\text { on forest certification and a rejection of illegally- } \\
\text { harvested timber }\end{array}$ & & $\bullet$ & & & \\
\hline $\begin{array}{l}\text { High risks and unequal conditions for wood market } \\
\text { actors due to introduction of export quotas }\end{array}$ & & • & • & & \\
\hline
\end{tabular}

Similarly to mass media expectations, all expert expectations have been split into opportunities and threats based on their positive or negative nature expressed by respondents. Table 5, which they have been compiled into, demonstrates that judged by expert expectations the positive outcomes of Russian accession to the WTO are likely to prevail in the forest sector.

Table 5 Potential opportunities and threats for the Russian forest sector within the WTO (according to forest experts).

\section{OPPORTUNITIES}

Easier access of Russian forest companies to foreign markets

Russia will have to follow the WTO rules; a lower possibility for discrimination of foreign forest companies; more transparency in wood trade

Increased amount of logging

Increased trade in wood

The priority in trade will be given to wood products coming from certified sources

Increased control for wood products

\section{THREATS}

Increased competition in the forest sector (also from abroad)

Non-competitiveness of Russian companies in producing wood products of high quality and deep processing

More expensive timber due to increased spendings on forest certification and a rejection of illegally-harvested timber

High risks and unequal conditions for wood market actors due to introduction of export quotas 
Examination of the nature of concerns and hopes for the Russian forest sector associated with the WTO has been accomplished through the PESTLE analysis (Table 6) and has one more time demonstrated that experts like the mass media expect mainly economic effects ( 7 factors). Legal expectations (2) are associated with controlling the rotation cycle of wood products and legalization of tree logging. The only technological outcome of the membership is expected to trigger an increased use of forest certification and the only political guarantee the abidance by the WTO rules in wood trade. No social or environmental effects have been expressed be respondents of the questionnaire.

Table 6 PESTLE analysis of anticipated changes in the Russian forest sector due to the WTO membership (according to forest experts).

\begin{tabular}{|c|c|c|}
\hline POLITICAL & ECONOMIC & SOCIAL \\
\hline $\begin{array}{l}\text { - Russia will have to follow the } \\
\text { WTO rules; a lower possibility for } \\
\text { discrimination of foreign forest } \\
\text { companies; more transparency in } \\
\text { wood trade }\end{array}$ & $\begin{array}{l}\text { - Easier access of Russian forest companies to } \\
\text { foreign markets } \\
\text { - Increased competition in the forest sector (also } \\
\text { from abroad) } \\
\text { - Increased trade in wood } \\
\text { - Increased export of wood and import of wood } \\
\text { products } \\
\text { - Non-competitiveness of Russian companies in } \\
\text { producing wood products of high quality and deep } \\
\text { processing } \\
\text { - More expensive timber due to increased } \\
\text { spendings on forest certification and a rejection of } \\
\text { illegally-harvested timber } \\
\text { - High risks and unequal conditions for wood } \\
\text { market actors due to introduction of export quotas }\end{array}$ & \\
\hline TECHNOLOGICAL & LEGAL & ENVIRONMENTAL \\
\hline $\begin{array}{l}\text { - The priority in trade will be given } \\
\text { to wood products coming from } \\
\text { certified sources }\end{array}$ & $\begin{array}{l}\text { - Increased control for wood products } \\
\text { - Legalization of tree logging }\end{array}$ & \\
\hline
\end{tabular}

Main opportunities and threats for the Russian forest sector within the WTO according to the mass media and the expert community

The triangulation approach we have chosen for the data collection and analysis implicates crossverification of our results derived from the mass media content analysis and the expert interview. Tables 9 and 10 bring together previously discussed attitudes of both stakeholder groups ranged in a descending order by frequency of mentioning (thus, with 1 indicating the most likely outcome of the Russian entry to the WTO). The opinions highlighted with bold italic are those opinions, which coincide in stated attitudes of journalists and experts and therefore, perceived as the most probable effects the WTO would have on the Russian forest industry and wood trade. 
Thus, comparison of possible benefits for the Russian forest sector arising from the WTO membership (Table 7) demonstrates, that both mass media and experts see the WTO as a potential for opening foreign markets to Russian companies and giving a boost for the trade in wood. They also expect that the WTO will contribute to a wider application of forest certification and harmonization of Russian and international technical standards in forestry. To a lesser extent, but nevertheless by general consent, the journalists and the experts forecast intensified logging and more transparent and fair wood trade in future as the result of the Russian accession to the WTO. Both focus groups are mainly pointing out economic opportunities opening up with the membership, however also mentioning legal, technological and environmental outcomes. Social long-term effects in the Russian forest sector are out of the scope of the media and experts' major concern.

Table 7 Comparison of potential opportunities for the Russian forest sector within the WTO based on the mass media content analysis and the questionnaire of expert opinion.

\begin{tabular}{|c|c|}
\hline & \\
\hline $\begin{array}{l}\text { Mass media } \\
\text { 1. Better availability of foreign forest machinery, materials, chemicals and } \\
\text { spare parts; more intensive modernization and better quality of Russian } \\
\text { forest products } \\
\text { 1. More investments into wood processing industry, logging and } \\
\text { ecologically-friendly manufacturing (incl. foreign investments); more } \\
\text { transparent and attractive investment climate } \\
\text { 2. Easier access of Russian wood products to foreign markets } \\
\text { 2. Adjustment of Russian technical standards in forestry to international } \\
\text { ones; increased use of forest certification } \\
\text { 3. More transparent and easier custom formalities } \\
\text { 3. More competitive prices for forest products } \\
\text { 3. Increased amount of logging } \\
\text { 4. Adoption of environmental laws sound with international } \\
\text { 4. Harmonization of Russian wood-trade related legislation with other } \\
\text { members of the WTO } \\
\text { 4. Increased trade in round wood } \\
\text { 4. Clear and transparent mechanisms of control over the implementation of } \\
\text { forest protection legislation } \\
\text { 4. Development of ecologically-friendly industries } \\
\text { 4. Less ecological protectionism } \\
\text { 4. Increased profit for SME due to cheaper raw materials } \\
\text { 4. More intensive use of wood pellets due to increased prices of natural gas } \\
\text { 4. Increased amount of foreign companies in Russia }\end{array}$ & $\begin{array}{l}\text { Experts } \\
\text { 1. Easier access of Russian forest } \\
\text { companies to foreign markets } \\
\text { 1. The priority in trade will be given } \\
\text { to wood products coming from } \\
\text { certified sources } \\
\text { 1. Increased trade in wood } \\
\text { 2. Legalization of tree logging } \\
\text { 2. Russia will have to follow the } \\
\text { WTO rules; a lower possibility for } \\
\text { discrimination of foreign forest } \\
\text { companies; more transparency in } \\
\text { wood trade } \\
\text { 2. Increased control for wood } \\
\text { products }\end{array}$ \\
\hline
\end{tabular}


Turning to potential threats associated with Russia being a member of the WTO, experts and journalists unanimously raise a concern that this change might enhance competition in the Russian forest sector and some of Russian forest industry companies might not survive through it, especially those enterprises which specialize in production of value-added wood products (Table 8). Both experts and the mass media forecast a rise in prices of timber with the mass media tracing it to a deficit of raw timber on the domestic market as the result of higher amounts of export from Russian and experts explaining it by additional spendings of forest companies for forest certification. All of the above mentioned threats are of an economic nature, what demonstrates that neither journalists nor experts see urgent potential social, environmental, political, legal or technological threats for the Russian forestry within the WTO.

Table 8 Comparison of potential threats for the Russian forest sector within the WTO based on the mass media content analysis and the questionnaire of expert opinion.

\begin{tabular}{|c|c|}
\hline $\begin{array}{l}\text { Mass media } \\
\text { 1. Increased export of raw timber; temporary deficit of it on the } \\
\text { home market; increase in prices of timber } \\
\text { 2. Increased competition of foreign companies; disappearance of } \\
\text { uncompetitive Russian companies, increase of unemployment, } \\
\text { decrease of tax payments to local budgets; Russian consumers } \\
\text { will prefer imported wood products } \\
\text { 3. Stagnation of forest machinery manufacturing } \\
\text { 3. Complications for forestry investment projects (especially } \\
\text { those at the stage of building facilities or beginning to); } \\
\text { worsening of the investment potential of the Russian forest } \\
\text { industry } \\
\text { 4. Decline of pulp and paper, furniture and wood-processing } \\
\text { industry; increased amount of imported pulp, paper and wood } \\
\text { products } \\
\text { 4. More foreign companies in Russia } \\
\text { 4. Less Russian wood products on the international market } \\
\text { 4. Decrease of Russian SME enterprises in forestry } \\
\text { 4. Development of more ecologically "dirty" industries, } \\
\text { 4. Stronger invasion of alien species of plants and animals } \\
\text { technologies }\end{array}$ & $\begin{array}{l}\text { Experts } \\
\text { 1. Increased competition in the forest sector (also } \\
\text { from abroad) } \\
\text { 2. Non-competitiveness of Russian companies in } \\
\text { producing wood products of high quality and } \\
\text { deep processing } \\
\text { 2. High risks and unequal conditions for wood } \\
\text { market actors due to introduction of export } \\
\text { quotas } \\
\text { 3. More expensive timber due to increased } \\
\text { spendings on forest certification and a rejection } \\
\text { of illegally-harvested timber }\end{array}$ \\
\hline
\end{tabular}




\section{Discussion and Conclusions}

The overview of targeting short-term effects of Russian WTO membership on its forest industry and trade has demonstrated that the first sectoral impacts of the WTO were noted within several months from the entry with the media highlighting an additional load of paperwork for the export of forest products within a new system of licensing. With the Ministry of Industry and Trade of the Russian Federation now distributing licenses for export of forest products, many logging companies having debts in forest lease together with new-to-export companies did not get a right for obtaining such license, however many no-longer existing companies did. Additional resentment of logging companies was caused by the fact that the list of duly-paying forest lessees was updated by the Federal Forest Agency just once a year. Another short-coming was revealed in softwood logs classifications causing stagnation of export of Russian softwood logs to Finland and giving grounds for Finland's accusations of Russia hindering trade in wood in March of 2013. A bigger decrease in export tariffs for processed timber also caused a problem with conversion of logs into sawnwood of poor quality, demonstrating a need for more precise control over the quality of exported wood products. From another side, a positive trend was observed in prevention of illegal trade - wood resources were included into a list of strategically important goods and resources in September 2012 and illegal commerce of them became a criminally punishable act. The timing of the law modification indicates its possible relation to a decrease of tariffs as the result of Russia joining the WTO.

Analyzing relevant media content (10 news articles) and surveying forest experts (5 professionals), which were carried out in the study, demonstrated that the WTO is perceived as a highly potential platform for accelerating trade in forest products and opening up foreign markets to Russian forest companies. Experts and journalists believe that within the WTO there will be a wider use of forest certification and that Russian technical standards in forestry will be subjected to harmonization with international ones. In a smaller degree both focus groups forecast more logging in Russian forests and development of non-discriminatory wood trade triggered by Russian participation in the WTOregulated trade. It is noteworthy, that journalists and experts are more concerned about economic opportunities rather than legal, technological and environmental outcomes of the membership not to speak of social long-term opportunities which mostly stay out of the scope of their projections. According to analyzed expert and mass media opinions the most probable negative change which the Russian forest sector is likely to face within the WTO is an increased competition and breaking down of uncompetitive Russian forest companies as the result of this process. Moreover, prices of timber are believed to increase due to a domestic deficit of raw timber forecasted by the mass media and a raise in spendings for forest certification, which is likely to happen according to surveyed experts. 
Once again, expected threats for the Russian forest industry and wood trade are connected to the economy, what might indicate that neither the mass media nor experts do anticipate serious social, environmental, political, legal or technological threats for the Russian forest sector under the WTO or these impacts are more difficult to predict and, therefore, left outside of forecasts. Nevertheless, the significance of other effects should not be diminished, as new circumstances of Russian wood trade within the WTO might have other sectoral impacts: a potential for alterations in the forest area, age structure of forests, soil condition and amount of forest damages; changes in forest sector workforce and well-being of workers; effects on recreational forest services and multifunctionality of forests; revision of the current forest legislation and many others. Therefore, these topics should also deserve a special attention and a detailed investigation by journalists, forest experts and researchers in future.

A general picture of mass media and expert expectations is rather optimistic. In the analyzed news articles potential opportunities for the Russian forest sector constitute $57 \%$ of expressed opinions and in expert interviews $-60 \%$, what demonstrates a rather positive attitude of both focus groups in regards to the Russian WTO entry. However, the optimism mainly applies to longer-term sectoral effects, as short-term impacts are rather negative. Moreover, the optimistic scope of the WTO impact on the Russian forest industry and trade revealed in the present research should be taken rather conditionally, as it might have arisen from the purposive and convenience sampling of the mass media material and targeted experts. The findings indicate that the mass media is giving a wider array of potential opportunities and threats for the Russian forest sector as the result of its accession to the WTO rather than the expert community. While the experts are mainly covering questions of competition, market access and certification, the mass media is raising additional aspects like modernization of the forest sector, custom procedures, forest-related legislation, investment climate and position of small and medium-sized enterprises in new market conditions. This might result from the fact that news articles outnumbered expert opinions two to one or might be explained by journalists' attempt to reach a wider audience by addressing a wider range of issues.

The chosen data collection methods - media content analysis and expert questionnaire have proven themselves to be rather suitable methods for the present study generating comprehensive answers. PESTLE and triangulation as data analysis tools have contributed to a more detailed coverage of potential opportunities and risks for the Russian forest sector associated with the WTO entry and deeper understanding of their complex nature.

\section{References}

1. Fink, G. 1995. The GATT and Post Communist countries: past and present. In The world economy after the Uruguay Round, Breuss, F. (Ed.), Service Fachverlag, Vienna, Austria, pp. 219-246.

2. Ernst \& Young. 2012. Vtorična dlja Rossii? Vstuplenie Rossii v VTO: analitičeskij obzor. [Secondary for Russia? Russian entry to the WTO: analytic outlook]. Rossiskaja ekonomitšeskaja škola, Moscow, Russia, 92 pp. Available online: http://es.slideshare.net/NewEconomicSchool/ss12725248 (accessed on 22 February 2015). 
3. Tovarnaja nomenklatura vnešneekonomitšeskoi dejatelnosti Tamožennogo sojuza. Available online: http://www.tks.ru/db/tnved/tree (accessed on 22 February 2015).

4. Consultant Plus. 2012. Pravitelstvo RF utverdilo tarifnye kvoty na eksport otdelnyh vidov lesomaterialov hvojnyh porod. [The Government of the Russian Federation has set tariff quotas on export of specific types of sawnwood of softwood species]. Available online: http://www.consultant.ru/law/hotdocs/20206.html\#.UgDWNqKpqfV (accessed on 22 February 2015).

5. Dement'eva, E. 2012. Kvoty vvodjat - ščepki letjat. [Quotas are introduced - wood chips fly]. Available online: http://www.rg.ru/2012/09/13/reg-sibfo/forum.html (accessed on 22 February 2015).

6. Alekseeva, A. 2012. VTO idët lesami. [WTO walks over forests]. Available online: http://fontanka.fi/articles/6753/ (accessed on 22 February 2015).

7. Schönberg, K. 2013. Metsäteollisuus: Venäjä rikkoo WTO-säännöksiä. Available online: http://yle.fi/uutiset/metsateollisuus venaja rikkoo wto-saannoksia/6532461 (accessed on 22 February 2015).

8. Luukko, J. 2013. Stubb: Venäjä rikkoo WTO-sopimusta. Available online: http://yle.fi/uutiset/stubb_venaja_rikkoo_wto-sopimusta/6534719 (accessed on 22 February 2015).

9. WTO. 2013. EU files dispute against Russia on recycling fee on motor vehicles. Available online: http://wto.org/english/news e/news13 e/ds462rfc 09jul13 e.htm (accessed on 22 February 2015).

10. Mutovina, O. 2013. Kruglyj prevraščaetsja v "kvadratnyj". [Round turns to "square"]. Available online: http://pda.lesvesti.ru/news/capital/4703/ (accessed on 22 February 2015).

11. Federal Customs Service. 2013. Vozbuždeno dvadcat' ugolovnyh del po faktam kontrabandy lesa. [Twenty criminal cases have been initiated over illegal wood trafficking]. Available online: http://xn--80aaaaafqhbdkc3dflnfap7a7an7ae0s2cj.xn--p1ai/index.php (accessed on 22 February 2015).

12. Federal Customs Service of Siberia. 2013. Za god tamoženniki Sibiri vozbudili 70 ugolovnyh del po faktam kontrabandy lesa i uklonenij ot uplaty tamožennyh pošlin pri lesoeèksporte. [During one year custom officers of Siberia have launched 70 criminal cases over illegal wood trafficking and evasion of custom duties for export of wood]. Available online: http://stu.customs.ru/index.php?option=com content\&view=article\&id=8554:-----70-------------\&catid=4:news\&Itemid=88 (accessed on 22 February 2015).

13. Rothbauer, P.M. 2008. Triangulation. In The Sage encyclopedia of qualitative research methods, Given, L.M. (Ed.), Sage Publications, Thousand Oaks, USA, pp. 893-895.

14. Petrov, V. 2012. Vot i VTO. V kakih uslovijah predstoit rabotat' lesnoj otrasli Rossii. [WTO, here we come. Which conditions the Russian forest sector will have to work in. Available online: http://www.lesovod.org.ua/node/15278 (accessed on 22 February 2015).

15. Lesnaja industrija. 2012. K čemu privedet vstuplenie v VTO? [What will the WTO accession lead to?]. Available online: http://www.lesindustry.ru/issues/li n4546/K chemu privedet vstuplenie v VTO 447/ (accessed on 22 February 2015).

16. Kramskih, A. 2012. Lesom rešili požertvovat'? [Have they decided to sacrifice forests?]. Available online: http://lesvesti.ru/news/capital/3507/ (accessed on 22 February 2015).

17. Tret'jakov, A. 2012. VTO prineset pljusy lesnomu kompleksu tol'ko pri sistempnoi gosudarstvennoj podderžke. [The WTO will bring benefit to the forest sector only with a systematic support of the government]. Available online: http://www.krassever.ru/articles/economics/biznes/39221/ (accessed on 22 February 2015).

18. Denisenko, E. 2012. Ne uspeli. [We have missed it]. Available online: http://expert.ru/northwest/2012/05/ne-uspeli/ (accessed on 22 February 2015).

19. Rbk. 2012. Dialog - rossijskij les v VTO (video). [Dialog - the Russian forest in the WTO]. Available online: http://www.youtube.com/watch?v=Dw 3Vzg8NT0 (accessed on 22 February 2015). 
20. RIA. 2013. Rossija I VTO: "zelenaja" storona voprosa. [Russian and the WTO: "green" side of the question]. Available online: http://ria.ru/earth/20131101/974196400.html (accessed on 22 February 2015).

21. Žukov, A. 2012. Lesopererabotčiki prognozirujut rost cen na syr'e v svjazi s vstupleniem Rossii v VTO. [Wood-processing industry forecasts an increase of prices for the raw material as the result of the Russian accession to the WTO]. Available online: http://rbcdaily.ru/industry/562949983967585 (accessed on 22 February 2015).

22. Švec, I. 2011. Rossija idet v VTO. Čto ždet lesnoj rynok? [Russia enters the WTO. What will the wood market face in future?]. Available online: http://oborudovaniederevo.ru/articles print.php?id=268 (accessed on 22 February 2015).

23. Rbk. 2012. Dialog - rossijskij les v VTO (video). [Dialog - the Russian forest in the WTO]. Available online: https://www.youtube.com/watch?v=wph-fvyN3Ac (accessed on 22 February 2015).

24. Saumure, K. and Given, L.M. 2008. Non-probability sampling. In The Sage encyclopedia of qualitative research methods, Given, L.M. (Ed.), Sage Publications, Thousand Oaks, USA, pp. 563564.

25. Bensoussan, B.E., Fleisher, C.S. 2008. Analysis without paralysis. FT Press, Old Tappan, USA, 240 pp.

(C) 2015 Maximova J., Karjalainen T., Pykäläinen, J. 